\title{
Communication
}

\section{The Potential Role of Nonhuman Primate Models to Better Comprehend Early Life Immunity and Maternal Antibody Transfer}

\author{
Julie Sartoretti ${ }^{1,2}$ and Christiane S. Eberhardt ${ }^{1,2,3,4, *}$ \\ 1 Center for Vaccinology, Department of Pathology and Immunology, Faculty of Medicine, \\ University of Geneva, 1211 Geneva 4, Switzerland; julie.sartoretti@unige.ch \\ 2 Department of Woman, Child and Adolescent Medicine, Geneva University Hospitals and Faculty of \\ Medicine, 6 rue Willy-Donze, 1211 Geneve 4, Switzerland \\ 3 Center for Vaccinology, University Hospitals of Geneva, 1205 Geneva, Switzerland \\ 4 Emory Vaccine Center, Emory University, Atlanta, GA 30322, USA \\ * Correspondence: Christiane.eberhardt@unige.ch
}

Citation: Sartoretti, J.; Eberhardt, C.S. The Potential Role of Nonhuman Primate Models to Better Comprehend Early Life Immunity and Maternal Antibody Transfer. Vaccines 2021, 9, 306. https:// doi.org/10.3390/vaccines9040306

Academic Editors: Nabila Seddiki and Roger Le Grand

Received: 12 February 2021

Accepted: 17 March 2021

Published: 24 March 2021

Publisher's Note: MDPI stays neutral with regard to jurisdictional claims in published maps and institutional affiliations.

Copyright: (c) 2021 by the authors. Licensee MDPI, Basel, Switzerland. This article is an open access article distributed under the terms and conditions of the Creative Commons Attribution (CC BY) license (https:// creativecommons.org/licenses/by/ $4.0 /)$.

\begin{abstract}
Early life immunity is a complex field of research and there are still gaps in knowledge regarding the detailed mechanism of maternal antibody transfer, the impact of maternal antibodies on infant vaccine responses and the ontogeny of human early life immunity. A comprehensive understanding is necessary to identify requirements for early life vaccines and to improve early childhood immunization. New immunological methods have facilitated performing research in the youngest, however, some questions can only be addressed in animal models. To date, mostly murine models are used to study neonatal and infant immunity since they are well-described, easy to use and cost effective. Given their limitations especially in the transfer biology of maternal antibodies and the lack of infectivity of numerous human pathogens, this opinion piece discusses the potential and prerequisites of the nonhuman primate model in studying early life immunity and maternal antibody transfer.
\end{abstract}

Keywords: early human life immunity; vaccinology; nonhuman primate model

\section{Introduction}

The ontogeny of early life immunity is a complex field of research, partly due to the vulnerable population of interest. In addition, the infant immune system has distinct features compared to adults, responding to the exclusive conditions during this initial phase of life. Being born from a mostly sterile environment [1], the newborn lacks specific immune memory against aggressive microbes and is only passively protected through transferred maternal antibodies. While the immune system needs to develop a certain tolerance against commensal microorganisms, it is required to balance it against an effective immune response to pathogens. These diametrical requirements explain the vulnerability of the youngest facing infectious diseases. Neonates are at risk of developing fulminant severe infections against most pathogens, and infants tend to have more severe viral infections and an increased susceptibility to various bacteria, for example encapsulated germs, and in particular Streptococcus pneumoniae [2]. In 2018, the mortality rate for children under the age of five years was 3.9\%, and approximately half of it was due to communicable diseases, which translated to 2.5 million young children dying that year of potentially vaccine-preventable diseases [3]. This shows the need for a better understanding of early life immunity which could help improving immunization, thus saving lives. Nevertheless, several research hypotheses are difficult to investigate in human newborns calling for the optimal surrogate animal model. 
This opinion piece briefly summarizes the state of knowledge of early life immunity and of maternal antibody transfer, discusses currently used animal models and elaborates the potential role of nonhuman primates (NHP) in addressing open research questions.

\subsection{Early Life Immune Responses}

Ontogeny of early life immunity describes the development of immune responses in newborns and infants usually up to the age of 2 years, and differences to the adult innate and adaptive immune system have been reviewed in detail elsewhere [2,4]. Briefly, studies on whole blood and innate blood cell subsets have shown that the initial innate cytokine signature which ultimately shapes the adaptive immune response evolves with age. The anti-inflammatory state observed in preterm neonates and at birth can be explained as adaptive mechanism to prevent abortion during pregnancy and to facilitate the maternofetal coexistence [5]. In vitro Toll-like receptor stimulation of whole blood and innate blood cell subsets elicits at birth an anti-inflammatory environment and cytokines promoting $\mathrm{T}_{\mathrm{H}} 17 \mathrm{~T}$ cells, followed after the first weeks of life by a capability to induce antiviral responses. While there is an increase in proinflammatory cytokines over the first months of life and $\mathrm{T}_{\mathrm{H}} 17 \mathrm{~T}$ cell polarizing cytokines decrease, the $\mathrm{T}_{\mathrm{H}} 1 \mathrm{~T}$ cell supporting environment only reaches adult levels at around 2 years of life (reviewed in [2]). Innate cells such as dendritic cells and neutrophils have quantitative and functional differences compared to adult cells, showing for example decreased capacity to present antigens or to respond to stimulation $[4,6]$.

These regulated innate responses elicit early life CD4 T cells that are characterized by a marked polarization toward $\mathrm{T}_{\mathrm{H}} 2$ and $\mathrm{T}_{\mathrm{H}} 17$ phenotypes $[7,8]$. Subsequently reduced $\mathrm{T}_{\mathrm{H}} 1$ responses are associated with a higher risk of intracellular infections [4] and diminished responses to immunization [9]. Additionally, compromised T cell functions are not linked to interference with maternal antibodies but rather result from suboptimal interactions with antigen-presenting cells [10,11], explaining a decreased B cell activation and response. Impaired germinal center formation is thought to be caused by a delayed development of follicular dendritic cells [12], subsequent decreased T follicular helper responses [13,14] and a low germinal center output of differentiated memory B cells and antibody-secreting plasma cells [8]. Hence the relative dominance of extrafollicular B cell responses eliciting short-lived plasma cells which explain the observed low affinity antibodies that rapidly wane [10]. It has also been shown that the survival of plasma cells in the bone marrow is shortened in early life [15]. This translates clinically into diminished antibody responses and the need for multiple booster immunizations during the first year of life. Additionally, vaccination protocols tend to be less successful when starting too early after birth with short intervals between doses [10]. Even though hepatitis B vaccine, which is given at birth, has been often cited as counter-example, seroconversion after the birth dose can be as low as $10 \%$ [16] and booster immunizations are needed to confer optimal protection [17].

The ontogeny of the immune system in early life with distinct features depending on the different developmental phases shows the need for neonatal vaccine formulations that fulfill the complex requirements. New immunological research techniques allow to generate reliable data with less than $10 \mathrm{~mL}$ of blood [4], enabling sufficient sample collections on newborns and help broaden research possibilities with human samples. However, there is still a need for adequate animal models such as to test new vaccine formulations and adjuvants or to perform challenge experiments.

\subsubsection{Animal Models Reflecting Human Early Life Responses}

Animal models developed to better characterize immune responses in early life have to fulfill several criteria such as analogy to the human immune system, feasibility and cost-effectiveness. The greatest challenge is that the ontogeny of immune responses of chosen animals need to be as close as possible to humans and that the timing of different developmental stages in the animal compared to humans need to be meticulously defined. 
Especially in terms of feasibility and cost-effectiveness, it is obvious that the murine model is an unmissable option and has been the main animal model used in pediatric vaccinology and immunology to date. Mice have similar early life immune patterns as infants: they show similar distinct innate responses, elicit limited Th1 (IFN- $\gamma$ ), increased $\mathrm{T}_{\mathrm{H}} 2$ responses [18], and lower $\mathrm{CD}^{+} \mathrm{T}$ cell responses [10]. It has been shown that early $\mathrm{B}$ cell activation is limited, germinal center responses are impaired [19] and that antibodies rapidly wane after vaccination $[10,19]$, reflecting a reduced plasma cell persistence in the bone marrow [20]. Even though immune read-outs detectable in the peripheral blood seem identical between human infants and mice, it is still unclear if the underlying mechanisms are similar between both species [20]. Usually 1-week-old pups are used as neonatal model, and mice aged 2-3 weeks for infant models. Different strains of laboratory mice also elicit distinct immune responses. For example, Balb/c mice tend to skew $\mathrm{T}$ cell responses toward $\mathrm{T}_{\mathrm{H}} 2$ phenotypes and often elicit higher antibody titers, whereas C57BL/6 mice polarize toward $\mathrm{T}_{\mathrm{H}} 1$ and cellular immune responses [21], indicating the necessity to wisely choose the optimal mouse strain for each experiment. Limitations of the murine model include their short lifespan which can impede investigations such as long-term effects of vaccination. Most importantly, human infectious agents are not always infectious or symptomatic in mice, which renders this animal model inadequate for challenge experiments for those diseases. Human influenza virus does not naturally infect mice [22] and virus adaptations had to be made for murine influenza models, or different bacterial strains need to be used, as done for Staphylococcus aureus to mimic human intraperitoneal infection [22]. In order to overcome these challenges, humanized mouse models have been engineered, for example through human hematopoietic stem cell transfer to immunodeficient neonatal mice. More than 4 weeks after transfer, these mice were shown to develop functional adaptive immune responses, in particular regarding $\mathrm{B}, \mathrm{T}$ and dendritic cells, and susceptibility to some human viral infections such as Epstein-Barr virus [23] (reviewed in detail in [24]). Despite those constraints, murine models are relatively inexpensive and easy to use and thus are model of choice when suitable in responding to specific early life immunity questions.

\subsubsection{What Nonhuman Primate Models Can Add}

NHPs have unmatched genetical, physiological and behavioral resemblances with humans [25] and Chimpanzees (Pan troglodytes) are the most closely related. However, they are rarely used because of their endangered status, availability and cost. Hence less related monkeys, called Old World Monkeys, are currently employed, such as African green monkeys (Chlorocebus aethiops), rhesus monkeys (Macaca mulatta) and other types of macaques [21].

Some studies necessitate animal models that can mimic the pathophysiology of infections found in humans. Compared to murine models, there are multiple pathogens that affect NHPs and humans in the same way, such as Zika, Ebola, dengue [26] and chikungunya [27] viruses and Mycobacterium tuberculosis [28], whereas African green monkeys and macaques are not susceptible to human metapneumovirus [29]. Of special interest for early life immunity is the respiratory syncytial virus (RSV), for which symptoms and age-dependent severity are similar in both species [30]. NHPs have also been used as model in the field of vaccinology to compare the efficacy of whole-cell pertussis vaccine with the acellular vaccine in infant baboons. Wolfe and colleagues chose NHPs as they were the animal model closest related to humans [31] with similar symptomatology and contamination route [32]. The use of NHPs allowed to compare pertussis infection in naïve animals, animals vaccinated with acellular pertussis vaccine or whole-cell vaccine and convalescent animals. Results confirmed a finding already suspected in humans: acellular pertussis vaccine is less efficient in preventing infection and further transmission compared to the whole-cell pertussis vaccine [32]. Nevertheless, the NHP model is very complex given a variety of NHP species that have distinct features. It also has several practical limitations: the total number of animals per study and the number of samples taken per animal are strictly limited by law. It remains a costly model which needs special care 
facilities and training [4]. Immunological reagents validated for NHP can be scarce [32], but might often be replaced by those used for humans as they can be cross-reacting [26].

However, a fundamental question is the adequacy of the infant NHP model for human infants. The similarities in immune age-related changes between NHPs and humans are important to decipher before employing NHPs in the assessment of early life immunity. We know that NHPs have a similar immunosenescence as humans [25]. In terms of early life immunity, there are only few studies that show a similar development of the immune system during fetal life compared to humans [33], but there are many unknowns regarding the early life NHP immune system.

\subsubsection{Next Steps to the Use of NHPs in Assessing Early Life Responses}

Thorough studies are needed to determine if NHPs are an adequate model to parallel the ontogeny in humans. We first need to fully comprehend the developmental stages of the immune system and their timing, to then determine what age in NHPs correspond to human neonates or infants. For mice, 1-week-old pups are used as model for human neonates, whereas mostly 3-weeks-old mice are used as surrogate for infants. We suggest performing for example a vaccine study characterizing in detail the immune response to routine childhood immunization in NHPs and to compare these findings to humans. If analogies are confirmed, NHP could be a promising model to use in challenge experiments and in the assessment of reactogenicity and immunogenicity of novel adjuvants that could help improve early life immunization.

Another potential advantage of infant NHPs would be the assessment of mucosal immune responses to vaccination similar to adult models for RSV and SARS-CoV-2 [34,35]. Local vaccines for strictly mucosal pathogens aiming to boost IgA levels are currently studied, for example nasal Bordetella pertussis vaccination [36], or are already employed such as rotavirus vaccines. NHPs could help to better assess local immune responses, to understand mechanisms of asymptomatic colonization and to test efficacy of new candidates in challenge experiments. However, prerequisite is a careful validation of the NHP model $[37,38]$.

\subsection{Transfer of Maternal Antibodies}

Passively transferred maternal antibodies provide initial protection to the newborn at birth. Maternal IgG antibodies are mostly transferred through the placenta while IgA are transmitted via breastfeeding and are mainly protecting the mucosal lining of the infant. Maternal antibodies are known to progressively wane after birth, creating a window of vulnerability in the first months of life until infants elicit their own active immunity through vaccination and exposure. There are two approaches to shorten this vulnerable period: early life immunization and maternal vaccination with subsequent transplacental transfer of maternal antibodies. With the introduction of pertussis vaccination during pregnancy less than a decade ago, there is increasing research interest in the optimal timing of maternal immunization, the mechanisms of transplacental transfer and the influence of maternal antibodies on infant vaccination. Nevertheless, maternal vaccination has been recommended by the WHO since the 1960s for tetanus [39,40], an intervention that has greatly decreased neonatal mortality and morbidity [40]. The first studies date from the same period when Gitlin and colleagues injected pregnant women with radioiodinated $\gamma_{2}$-globulin and labeled albumin. They demonstrated at birth that mainly IgG was transferred in a time-dependent manner to the newborn, reaching a maternal/infant ratio of 1 at around 3 weeks after injection [41]. The mechanism was later explained by the neonatal Fc-receptors ( $\mathrm{FcRn}$ ) which help transfer albumin and IgG through the placental membrane to the fetus [5]. Interestingly, this receptor can be saturated [5] as seen in lower antibody transfer ratios in mothers with higher antibody titers [42]. It was also revealed that IgG subclasses do not interact similarly with the neonatal Fc receptor at the placental membrane. Indeed, there is a greater transfer of $\mathrm{IgG}_{1}$ compared to $\operatorname{IgG}_{2}$, while $\mathrm{IgG}_{4}$ and $\mathrm{IgG}_{3}$ have intermediate affinities to the $\mathrm{FcRn}$ [43]. Additionally, there is 
an impact of the Fc glycosylation patterns on antibody transfer rates, with a preferential transplacental transfer of galactosylated $\operatorname{IgG}_{1}$ antibodies [43]. The glycosylation pattern seems to depend on the timing after infection or vaccination and might differ between antibodies elicited following primary and secondary responses [44], and also changes with gestational age at birth [45]. These might be some underlying mechanisms for the observation that antibodies with different antigen specificities tend to be transferred at different rates, as it has been described for antibodies against influenza, tetanus toxoid, herpes simplex virus, streptolysin $\mathrm{O}$, and Streptococcus pneumoniae [5].

Regarding the kinetics of antibody transfer, a metanalysis of 540 fetal IgG measurements revealed that antibodies are detectable at 17 weeks of gestational age (GA) and that they increase over time. In 258 paired measurements it was shown that a maternal/fetal ratio of 1 was reached at around 35 weeks of GA [46]. Palmeira and colleagues could detect antibody transfer as early as 13 weeks of GA, but showed a steady increase from 17 weeks of GA onwards [5]. The cumulative transfer of maternal antibodies over time is also underlined by the lower antibody titers found in preterm compared to term infants $[47,48]$. Parity, maternal age, type of delivery, and birthweight do not seem to have an influence on antibody transfer [49]. When recommending the optimal timing of maternal vaccination, it is important to understand the transfer kinetics. We could show that offspring from mothers immunized during the 2nd trimester (13-25 weeks of GA) rather than during the 3rd trimester ( $>25$ weeks of GA) had higher antibodies titers [50], and that early vaccination also benefited preterm neonates, even if the final titers of transferred antibodies were lower compared to term neonates $[50,51]$.

One of the open questions related to antibody transfer is the interaction of maternal antibodies with future childhood vaccination and a potential blunting of responses. Offspring of mothers immunized with tetanus-diphtheria-pertussis vaccine (Tdap) during pregnancy elicited lower antibody responses to pertussis toxin, even after the booster dose given at 11 months [52]. There are various hypotheses regarding the mechanism of interaction and influence of maternal antibodies on infant vaccine responses and are reviewed elsewhere [53]. Recently, it has been shown in a murine model that humoral responses to adjuvanted influenza vaccination were decreased in presence of maternal antibodies. However, higher maternal antibody titers at vaccination did not prevent $B$ cell activation nor formation of germinal centers. Yet, they affected differentiation of germinal center $B$ cells into plasma cells and memory B cells in a titer-dependent manner and influenced the $B$ cell receptor repertoire [11]. This indicates that maternal antibodies can interfere with infant B cells both in a quantitative and qualitative manner thus shaping infant's immune responses. However, even if interactions do occur, maternal immunization was found beneficial for both children and mother [54] and the clinical implication of decreased antibody responses has not been elucidated.

There is a need to understand ways of optimizing maternal antibody transfer without compromising future vaccination in the child, for example through a vaccine design or adjuvantation that enhances maternal $\mathrm{IgG}_{1}$ and $\mathrm{IgG}_{3}$ antibodies or $\mathrm{IgG}_{1}$ galactosylation, or through a better understanding of the timing of immunization. More research is needed to decipher the influence of maternal antibodies on the vaccine response in the offspring and on the elicited B cell repertoire. Especially the clinical relevance of blunted vaccine responses needs to be defined which could call for an adaptation of the infant's vaccination schedule if the mother was immunized during pregnancy.

\subsubsection{Animal Models to Study Kinetics and Quality of Maternal Antibody Transfer}

For research on maternal antibodies transfer, it is important to understand that humans have a hemomonochorial placenta with an active endosomal antibody transfer, mostly mediated by the neonatal Fc receptor localized on placental syncytiotrophoblasts [55,56], characteristics which greatly differ from most mammalian placentas. In mice, the placental membrane is hemotrichorial and maternal antibodies are mainly transferred by breastmilk [57]. Humanized FcRn mice, which lack mouse FcRn, were shown to transfer 
IgG transplacentally. However, the level of transferred antibodies was lower compared to titers achieved through subsequent nursing and gastrointestinal transfer, which is opposing to the modalities and kinetics of antibody transfer in humans [58]. Rabbits have a hemodichorial placental membrane, with the same limitations as mice. Sheep do have a hemomonochorial placenta but lack the human ability of transplacental protein transfer [59]. Guinea pigs also have a hemomonochorial placenta similar to humans but differ in the possession of a subplacenta [59]. Interestingly, they do express FcRn, not on the placenta but in their inverted yolk sac $[60,61]$ and IgG transfer during the end of pregnancy has similar kinetics as in humans [61,62]. Despite somewhat comparable mechanisms, antibody transfer in guinea pigs has been proven less efficient than in humans, limiting its use as a model [60]. A summary of the different animal models with their advantages and limitations can be found in Table 1 .

Table 1. Benefits and limitations of each model for early life immunity and maternal antibody transfer studies.

\begin{tabular}{|c|c|c|c|c|c|c|}
\hline Model & $\begin{array}{l}\text { Human-Like } \\
\text { Early } \\
\text { Life Immunity }\end{array}$ & $\begin{array}{l}\text { Type of Placenta } \\
\text { (No of Layers) }\end{array}$ & $\begin{array}{l}\text { Human-Like } \\
\text { FcRn }\end{array}$ & Pros & Cons & $\begin{array}{l}\text { Potential } \\
\text { Use }\end{array}$ \\
\hline Human & & Hemochorial (1) & Yes & & $\begin{array}{l}\text { Limited samples } \\
\text { Not useable for vaccine and } \\
\text { adjuvant development and } \\
\text { mechanistic in vivo studies }\end{array}$ & $\begin{array}{l}\text { TAT } \\
\text { ELI }\end{array}$ \\
\hline $\begin{array}{l}\text { Mouse } \\
\text { Conventional } \\
\text { Strains * } \\
\text { Engineered }\end{array}$ & $\begin{array}{l}\text { Yes, but corrected } \\
\text { for age (neonate }= \\
1 \text { weeks old pups, } \\
\text { vs. infant }=2-3 \\
\text { weeks old pups) }\end{array}$ & Hemochorial (3) & No $\left({ }^{\circ}\right)$ & $\begin{array}{l}\text {-Well- } \\
\text { established } \\
\text {-Cost- } \\
\text { effective } \\
\text { compared to } \\
\text { large animals }\end{array}$ & $\begin{array}{l}\text {-Breeding facility needed to } \\
\text { study specific mouse crosses } \\
\text {-Not adequate for assessing } \\
\text { antibody transfer at birth as } \\
\text { transfer through breastmilk } \\
\text { (peak only after around } 2 \\
\text { weeks) } \\
\text {-By respecting an interval of } 3 \\
\text { weeks for vaccine booster } \\
\text { doses, mice are already adult } \\
\text {-Short life span }\end{array}$ & ELI \\
\hline Rabbit/Sheep & NA & $\begin{array}{c}\text { Hemochorial (2: } \\
\text { rabbit) } \\
\text { (1: sheep) }\end{array}$ & No & & $\begin{array}{l}\text { Inadequate model for early } \\
\text { life and antibody transfer }\end{array}$ & None \\
\hline Guinea pig & NA & $\begin{array}{l}\text { Hemochorial (1, } \\
\text { with a } \\
\text { subplacenta) }\end{array}$ & Yes & Cost-effective & $\begin{array}{l}\text { Guinea pig FcRn transfer is } \\
\text { less efficient than human FcRn }\end{array}$ & TAT (?) \\
\hline Piglets & $\begin{array}{c}\text { Shown for } \\
\text { example in BCG } \\
\text { vaccination [63] }\end{array}$ & Epitheliochorial & No & $\begin{array}{l}\text { Similar } \\
\text { responses as } \\
\text { humans to } \\
\text { some } \\
\text { pathogens }\end{array}$ & Large animal-model & ELI \\
\hline $\begin{array}{c}\text { NHP } \\
\text { (Baboons, } \\
\text { macaques) }\end{array}$ & Unknown yet & Hemochorial (1) & Yes & $\begin{array}{l}\text { Same } \\
\text { response as } \\
\text { humans to } \\
\text { many } \\
\text { pathogens } \\
\text { and vaccines }\end{array}$ & $\begin{array}{l}\text { Costly, special care facilities } \\
\text { needed and trained personal } \\
\text { Similarity in early life } \\
\text { immunity needs to be proven } \\
\text { before its use }\end{array}$ & $\begin{array}{c}\text { TAT } \\
\text { ELI (?) }\end{array}$ \\
\hline
\end{tabular}

ELI = early life immunity, TAT = Transplacental antibody transfer; (?) indicates a theoretical potential use that needs to be confirmed through comparative experiments, $\mathrm{NA}=$ no data available or not discussed. ${ }^{*} \mathrm{C} 57 \mathrm{BL} / 6$ mice elicit mostly a $\mathrm{T}_{\mathrm{H}} 1$ and cellular immune response, whereas Balb/c mice elicit responses that are skewed towards $\mathrm{T}_{\mathrm{H}} 2$ and antibodies. The crossing of male C57BL/ 6 mice and female Balb/c mice (CB6F1) is a model used for the transfer of (high titers of) maternal antibodies to the pups and to subsequently assess the influence of maternal antibodies on the infant vaccine response [11]. ${ }^{\circ}$ engineered mouse strains: similarities to humans in the assessment of ELI depend on mouse strains but need to be corrected for age (neonate vs. infant). For the transplacental IgG transfer in humanized FcRn mice it needs to be shown that antibody titers in the offspring are higher than in the mother as an indicator for sufficient similarities to humans.

\subsubsection{Role of NHP in Studying Maternal Antibody Transfer}

Old World monkeys, especially baboons and macaques, as well as great apes, have a placenta closest to humans, with a hemomonochorial membrane and similar placental 
formation [59]. Those primate species have corresponding transplacental antibody transfer mechanisms and express FcRn on their placental membrane cells [60]. There are few studies aiming to understand mechanisms of maternal antibody transfer in NHPs. In rhesus monkeys, IgG was shown to particularly increase during the last two weeks of pregnancy [64] and the same phenomenon was observed during the four last weeks of pregnancy in cynomolgus monkeys [65]. Between species, antibody transfer was variable, with higher antibody transfer in apes and Old World monkeys rather than New World monkeys, but was highest in humans, as the active transfer allowed for higher antibody titers in infants compared to their mothers [66]. This mechanism seems to lack in NHPs as they rely less on the passive protection after birth, and thus remain an incomplete model for maternal antibody transfer [66].

Besides, there is easy access to human umbilical cord blood samples and placenta to elucidate maternal antibody transfer [57] and to answer questions about the immune system at the time of birth. However, its composition is not identical to capillary blood samples of neonates, and thus should be interpreted with caution [67].

1.2.3. Next Steps to the Use of NHPs in Assessing Transfer and Influence of Maternal Antibodies

A NHP model could be used to identify means to improve maternal antibody transfer, assess in-depth the influence of maternal antibodies on the infant immune response to subsequent vaccination and the elicited B cell repertoire. Especially, information on protection against challenge as indicator for clinical relevance of described blunting in the vaccine response would be a valuable exploration. However, results from human studies show increasingly complex details of IgG-subclass and glycosylation-dependent transplacental transfer of antibodies. These findings already discovered in humans would need to be confirmed in NHPs before this model could be used to study materno-fetal antibody transfer and blunting of infants' immune responses.

\section{Conclusions}

There are gaps in knowledge regarding the ontogeny of early life immunity and the mechanisms and effects of maternal antibody transfer. Animal research models are needed to help find improved early life vaccine formulations that fulfill distinct immunological requirements and confer protection. Mouse models are widely used, however, have limitations in the non-infectivity of human pathogens and are not suited to study transplacental antibody transfer. NHP could be a promising model to study the immune response to vaccination in early life, especially regarding the clinical relevance of blunting through maternal antibodies, to assess mucosal immune responses to vaccination and to improve neonatal vaccine formulations. However, it is to date unknown if the ontogeny of early life immunity in nonhuman primates compares to humans with their distinct developmental stages. This calls for research to better understand the similitudes of early life immunity in humans and NHPs. We suggest conducting in-depth immunological studies with conventional childhood vaccines to prove the accuracy of an early life NHP model.

Author Contributions: Conceptualization, J.S. and C.S.E.; writing-original draft preparation, J.S.; writing-review and editing, C.S.E. All authors have read and agreed to the published version of the manuscript.

Funding: This research received no external funding.

Institutional Review Board Statement: Not applicable.

Informed Consent Statement: Not applicable.

Conflicts of Interest: The authors declare no conflict of interest. 


\section{References}

1. Wassenaar, T.M.; Panigrahi, P. Is a foetus developing in a sterile environment? Lett. Appl. Microbiol. 2014, 59, 572-579. [CrossRef] [PubMed]

2. Kollmann, T.R.; Levy, O.; Montgomery, R.R.; Goriely, S. Innate immune function by Toll-like receptors: Distinct responses in newborns and the elderly. Immunity 2012, 37, 771-783. [CrossRef]

3. World Health Organization. World Health Statistics 2020: Monitoring Health for the SDGs, Sustainable Development Goals; World Health Organization. Available online: https:/ /apps.who.int/iris/handle/10665/332070 (accessed on 27 November 2020).

4. Dowling, D.J.; Levy, O. Ontogeny of early life immunity. Trends Immunol. 2014, 35, 299-310. [CrossRef] [PubMed]

5. Palmeira, P.; Quinello, C.; Silveira-Lessa, A.L.; Zago, C.A.; Carneiro-Sampaio, M. IgG Placental Transfer in Healthy and Pathological Pregnancies. Clin. Dev. Immunol. 2012, 2012, 1-13. [CrossRef]

6. Kollmann, T.R.; Crabtree, J.; Rein-Weston, A.; Blimkie, D.; Thommai, F.; Wang, X.Y.; Lavoie, P.M.; Furlong, J.; Fortuno, E.S.; Hajjar, A.M.; et al. Neonatal innate TLR-mediated responses are distinct from those of adults. J. Immunol. 2009, 183, 7150-7160. [CrossRef] [PubMed]

7. Kollmann, T.R.; Levy, O.; Hanekom, W. Vaccine-induced immunity in early life. Vaccine 2013, 31, 2481-2482. [CrossRef]

8. Mohr, E.; Siegrist, C.-A. Vaccination in early life: Standing up to the challenges. Curr. Opin. Immunol. 2016, 41, 1-8. [CrossRef]

9. PrabhuDas, M.; Adkins, B.; Gans, H.; King, C.; Levy, O.; Ramilo, O.; Siegrist, C.-A. Challenges in infant immunity: Implications for responses to infection and vaccines. Nat. Immunol. 2011, 12, 189-194. [CrossRef]

10. Siegrist, C.-A. Neonatal and early life vaccinology. Vaccine 2001, 19, 3331-3346. [CrossRef]

11. Vono, M.; Eberhardt, C.S.; Auderset, F.; Mastelic-Gavillet, B.; Lemeille, S.; Christensen, D.; Andersen, P.; Lambert, P.-H.; Siegrist, C.-A. Maternal Antibodies Inhibit Neonatal and Infant Responses to Vaccination by Shaping the Early-Life B Cell Repertoire within Germinal Centers. Cell Rep. 2019, 28, 1773-1784.e5. [CrossRef]

12. Pihlgren, M.; Tougne, C.; Bozzotti, P.; Fulurija, A.; Duchosal, M.A.; Lambert, P.-H.; Siegrist, C.-A. Unresponsiveness to lymphoidmediated signals at the neonatal follicular dendritic cell precursor level contributes to delayed germinal center induction and limitations of neonatal antibody responses to T-dependent antigens. J. Immunol. 2003, 170, 2824-2832. [CrossRef] [PubMed]

13. Gavillet, B.M.; Eberhardt, C.S.; Auderset, F.; Castellino, F.; Seubert, A.; Tregoning, J.S.; Lambert, P.-H.; de Gregorio, E.; Giudice, G.D.; Siegrist, C.-A. MF59 Mediates Its B Cell Adjuvanticity by Promoting T Follicular Helper Cells and Thus Germinal Center Responses in Adult and Early Life. J. Immunol. 2015, 194, 4836-4845. [CrossRef]

14. Mastelic, B.; Kamath, A.T.; Fontannaz, P.; Tougne, C.; Rochat, A.F.; Belnoue, E.; Combescure, C.; Auderset, F.; Lambert, P.H.; Tacchini-Cottier, F.; et al. Environmental and T cell-intrinsic factors limit the expansion of neonatal follicular T helper cells but may be circumvented by specific adjuvants. J. Immunol. 2012, 189, 5764-5772. [CrossRef] [PubMed]

15. Belnoue, E.; Pihlgren, M.; McGaha, T.L.; Tougne, C.; Rochat, A.-F.; Bossen, C.; Schneider, P.; Huard, B.; Lambert, P.-H.; Siegrist, C.-A. APRIL is critical for plasmablast survival in the bone marrow and poorly expressed by early-life bone marrow stromal cells. Blood 2008, 111, 2755-2764. [CrossRef] [PubMed]

16. Chirico, G.; Belloni, C.; Gasparoni, A.; Cerbo, R.M.; Rondini, G.; Klersy, C.; Orsolini, P.; Filice, G. Hepatitis B Immunization in Infants of Hepatitis B Surface Antigen-Negative Mothers. Pediatrics 1993, 92, 717-719. [PubMed]

17. André, F.E.; Zuckerman, A.J. Review: Protective efficacy of hepatitis B vaccines in neonates. J. Med. Virol. 1994, 44, $144-151$. [CrossRef] [PubMed]

18. Dhakal, M.; Miller, M.M.; Zaghouani, A.A.; Sherman, M.P.; Zaghouani, H. Neonatal Basophils Stifle the Function of Early-Life Dendritic Cells To Curtail Th1 Immunity in Newborn Mice. J. Immunol. 2015, 195, 507-518. [CrossRef]

19. Aradottir Pind, A.A.; Dubik, M.; Thorsdottir, S.; Meinke, A.; Harandi, A.M.; Holmgren, J.; Del Giudice, G.; Jonsdottir, I.; Bjarnarson, S.P. Adjuvants Enhance the Induction of Germinal Center and Antibody Secreting Cells in Spleen and Their Persistence in Bone Marrow of Neonatal Mice. Front. Immunol. 2019, 10, 2214. [CrossRef] [PubMed]

20. Pihlgren, M.; Schallert, N.; Tougne, C.; Bozzotti, P.; Kovarik, J.; Fulurija, A.; Kosco-Vilbois, M.; Lambert, P.-H.; Siegrist, C.-A. Delayed and deficient establishment of the long-term bone marrow plasma cell pool during early life. Eur. J. Immunol. 2001, 31, 939-946. [CrossRef]

21. Vaccinology: Principles and Practice / Wiley. Available online: https://www.wiley.com/en-us/Vaccinology\%3A+Principles+ and+Practice-p-9781405185745 (accessed on 8 January 2021).

22. Colby, L.A.; Quenee, L.E.; Zitzow, L.A. Considerations for Infectious Disease Research Studies Using Animals. Comp. Med. 2017, $67,222-231$.

23. Traggiai, E.; Chicha, L.; Mazzucchelli, L.; Bronz, L.; Piffaretti, J.-C.; Lanzavecchia, A.; Manz, M.G. Development of a human adaptive immune system in cord blood cell-transplanted mice. Science 2004, 304, 104-107. [CrossRef]

24. Martinov, T.; McKenna, K.M.; Tan, W.H.; Collins, E.J.; Kehret, A.R.; Linton, J.D.; Olsen, T.M.; Shobaki, N.; Rongvaux, A. Building the Next Generation of Humanized Hemato-Lymphoid System Mice. Front. Immunol. 2021, 12, 643852. [CrossRef]

25. Messaoudi, I.; Estep, R.; Robinson, B.; Wong, S.W. Nonhuman Primate Models of Human Immunology. Antioxid. Redox Signal. 2011, 14, 261-273. [CrossRef]

26. Estes, J.D.; Wong, S.W.; Brenchley, J.M. Nonhuman primate models of human viral infections. Nat. Rev. Immunol. 2018, 18, 390-404. [CrossRef]

27. Broeckel, R.; Haese, N.; Messaoudi, I.; Streblow, D.N. Nonhuman Primate Models of Chikungunya Virus Infection and Disease (CHIKV NHP Model). Pathogens 2015, 4, 662-681. [CrossRef] 
28. Kaushal, D.; Mehra, S.; Didier, P.J.; Lackner, A.A. The non-human primate model of tuberculosis. J. Med. Primatol. 2012, 41, 191-201. [CrossRef] [PubMed]

29. MacPhail, M.; Schickli, J.H.; Tang, R.S.; Kaur, J.; Robinson, C.; Fouchier, R.A.M.; Osterhaus, A.D.M.E.; Spaete, R.R.; Haller, A.A. Identification of small-animal and primate models for evaluation of vaccine candidates for human metapneumovirus (hMPV) and implications for hMPV vaccine design. J. Gen. Virol. 2004, 85, 1655-1663. [CrossRef] [PubMed]

30. Sibal, L.R.; Samson, K.J. Nonhuman Primates: A Critical Role in Current Disease Research. ILAR J. 2001, 42, 74-84. [CrossRef] [PubMed]

31. Warfel, J.M.; Merkel, T.J. The baboon model of pertussis: Effective use and lessons for pertussis vaccines. Expert Rev. Vaccines 2014, 13, 1241-1252. [CrossRef]

32. Warfel, J.M.; Zimmerman, L.I.; Merkel, T.J. Acellular pertussis vaccines protect against disease but fail to prevent infection and transmission in a nonhuman primate model. Proc. Natl. Acad. Sci. USA 2013, 111, 787-792. [CrossRef]

33. Batchelder, C.A.; Duru, N.; Lee, C.I.; Baker, C.A.R.; Swainson, L.; Mccune, J.M.; Tarantal, A.F. Myeloid-lymphoid ontogeny in the rhesus monkey (Macaca mulatta). Anat. Rec. (Hoboken) 2014, 297, 1392-1406. [CrossRef] [PubMed]

34. Salisch, N.C.; Izquierdo Gil, A.; Czapska-Casey, D.N.; Vorthoren, L.; Serroyen, J.; Tolboom, J.; Saeland, E.; Schuitemaker, H.; Zahn, R.C. Adenovectors encoding RSV-F protein induce durable and mucosal immunity in macaques after two intramuscular administrations. NPJ Vaccines 2019, 4, 1-13. [CrossRef]

35. Corbett, K.S.; Flynn, B.; Foulds, K.E.; Francica, J.R.; Boyoglu-Barnum, S.; Werner, A.P.; Flach, B.; O’Connell, S.; Bock, K.W.; Minai, M.; et al. Evaluation of the mRNA-1273 Vaccine against SARS-CoV-2 in Nonhuman Primates. N. Engl. J. Med. 2020, 383, 1544-1555. [CrossRef]

36. Solans, L.; Locht, C. The Role of Mucosal Immunity in Pertussis. Front. Immunol. 2019, 9, 3068. [CrossRef] [PubMed]

37. Chege, G.K.; Steele, A.D.; Hart, C.A.; Snodgrass, D.R.; Omolo, E.O.; Mwenda, J.M. Experimental infection of non-human primates with a human rotavirus isolate. Vaccine 2005, 23, 1522-1528. [CrossRef] [PubMed]

38. Sestak, K.; McNeal, M.M.; Choi, A.; Cole, M.J.; Ramesh, G.; Alvarez, X.; Aye, P.P.; Bohm, R.P.; Mohamadzadeh, M.; Ward, R.L. Defining T-Cell-Mediated Immune Responses in Rotavirus-Infected Juvenile Rhesus Macaques. J. Virol. 2004, 78, 10258-10264. [CrossRef]

39. Newell, K.W.; Dueñas Lehmann, A.; LeBlanc, D.R.; Garces Osorio, N. The use of toxoid for the prevention of tetanus neonatorum. Final report of a double-blind controlled field trial. Bull. World Health Organ. 1966, 35, 863-871.

40. Thwaites, C.L.; Beeching, N.J.; Newton, C.R. Maternal and neonatal tetanus. Lancet 2015, 385, 362-370. [CrossRef]

41. Gitlin, D.; Kumate, J.; Urrusti, J.; Morales, C. The Selectivity of the Human Placenta in the Transfer of Plasma Proteins from Mother to Fetus*. J. Clin. Investig. 1964, 43, 1938-1951. [CrossRef]

42. De Moraes-Pinto, M.I.; Almeida, A.C.; Kenj, G.; Filgueiras, T.E.; Tobias, W.; Santos, A.M.; Carneiro-Sampaio, M.M.; Farhat, C.K.; Milligan, P.J.; Johnson, P.M.; et al. Placental transfer and maternally acquired neonatal IgG immunity in human immunodeficiency virus infection. J. Infect. Dis. 1996, 173, 1077-1084. [CrossRef]

43. Jennewein, M.F.; Goldfarb, I.; Dolatshahi, S.; Cosgrove, C.; Noelette, F.J.; Krykbaeva, M.; Das, J.; Sarkar, A.; Gorman, M.J.; Fischinger, S.; et al. Fc Glycan-Mediated Regulation of Placental Antibody Transfer. Cell 2019, 178, 202-215.e14. [CrossRef] [PubMed]

44. Atyeo, C.; Pullen, K.M.; Bordt, E.A.; Fischinger, S.; Burke, J.; Michell, A.; Slein, M.D.; Loos, C.; Shook, L.L.; Boatin, A.A.; et al. Compromised SARS-CoV-2-specific placental antibody transfer. Cell 2021, 184, 628-642.e10. [CrossRef] [PubMed]

45. Twisselmann, N.; Bartsch, Y.C.; Pagel, J.; Wieg, C.; Hartz, A.; Ehlers, M.; Härtel, C. IgG Fc Glycosylation Patterns of Preterm Infants Differ With Gestational Age. Front. Immunol. 2019, 9, 3166. [CrossRef] [PubMed]

46. Palfi, M.; Selbing, A. Placental Transport of Maternal Immunoglobulin G. Am. J. Reprod. Immunol. 1998, 39, 24-26. [CrossRef] [PubMed]

47. Van den Berg, J.P.; Westerbeek, E.A.M.; Smits, G.P.; van der Klis, F.R.M.; Berbers, G.A.M.; van Elburg, R.M. Lower Transplacental Antibody Transport for Measles, Mumps, Rubella and Varicella Zoster in Very Preterm Infants. PLoS ONE 2014, 9 , e94714. [CrossRef] [PubMed]

48. Lessa, A.L.S.; Krebs, V.L.J.; Brasil, T.B.; Pontes, G.N.; Carneiro-Sampaio, M.; Palmeira, P. Preterm and term neonates transplacentally acquire IgG antibodies specific to LPS from Klebsiella pneumoniae, Escherichia coli and Pseudomonas aeruginosa. FEMS Immunol. Med. Microbiol. 2011, 62, 236-243. [CrossRef] [PubMed]

49. Doroudchi, M.; Samsami Dehaghani, A.; Emad, K.; Ghaderi, A. Placental transfer of rubella-specific IgG in fullterm and preterm newborns. Int. J. Gynaecol. Obstet. 2003, 81, 157-162. [CrossRef]

50. Eberhardt, C.S.; Blanchard-Rohner, G.; Lemaître, B.; Boukrid, M.; Combescure, C.; Othenin-Girard, V.; Chilin, A.; Petre, J.; de Tejada, B.M.; Siegrist, C.-A. Maternal Immunization Earlier in Pregnancy Maximizes Antibody Transfer and Expected Infant Seropositivity Against Pertussis. Clin. Infect. Dis. 2016, 62, 829-836. [CrossRef]

51. Eberhardt, C.S.; Blanchard-Rohner, G.; Lemaître, B.; Combescure, C.; Othenin-Girard, V.; Chilin, A.; Petre, J.; Martinez de Tejada, B.; Siegrist, C.-A. Pertussis Antibody Transfer to Preterm Neonates after Second- versus Third-Trimester Maternal Immunization. Clin. Infect. Dis. 2017, 64, 1129-1132. [CrossRef]

52. Barug, D.; Pronk, I.; van Houten, M.A.; Versteegh, F.G.A.; Knol, M.J.; van de Kassteele, J.; Berbers, G.A.M.; Sanders, E.A.M.; Rots, N.Y. Maternal pertussis vaccination and its effects on the immune response of infants aged up to 12 months in the Netherlands: An open-label, parallel, randomised controlled trial. Lancet Infect. Dis. 2019, 19, 392-401. [CrossRef] 
53. Siegrist, C.A. Mechanisms by which maternal antibodies influence infant vaccine responses: Review of hypotheses and definition of main determinants. Vaccine 2003, 21, 3406-3412. [CrossRef]

54. Kachikis, A.; Englund, J.A. Maternal immunization: Optimizing protection for the mother and infant. J. Infect. 2016, 72, S83-S90. [CrossRef]

55. Saji, F.; Samejima, Y.; Kamiura, S.; Koyama, M. Dynamics of immunoglobulins at the feto-maternal interface. Rev. Reprod. 1999, 4, 81-89. [CrossRef]

56. Simister, N.E.; Story, C.M.; Chen, H.L.; Hunt, J.S. An IgG-transporting Fc receptor expressed in the syncytiotrophoblast of human placenta. Eur. J. Immunol. 1996, 26, 1527-1531. [CrossRef]

57. Hodgins, D.C.; Shewen, P.E. Vaccination of neonates: Problem and issues. Vaccine 2012, 30, 1541-1559. [CrossRef]

58. Borghi, S.; Bournazos, S.; Thulin, N.K.; Li, C.; Gajewski, A.; Sherwood, R.W.; Zhang, S.; Harris, E.; Jagannathan, P.; Wang, L.-X.; et al. FcRn, but not Fc $\gamma$ Rs, drives maternal-fetal transplacental transport of human IgG antibodies. Proc. Natl. Acad. Sci. USA 2020, 117, 12943-12951. [CrossRef] [PubMed]

59. Carter, A.M. Animal models of human placentation-A review. Placenta 2007, 28, S41-S47. [CrossRef] [PubMed]

60. Pentsuk, N.; van der Laan, J.W. An interspecies comparison of placental antibody transfer: New insights into developmental toxicity testing of monoclonal antibodies. Birth Defects Res. B Dev. Reprod. Toxicol. 2009, 86, 328-344. [CrossRef] [PubMed]

61. Barnes, J.M. Antitoxin transfer from mother to fœtus in the guinea-pig. J. Pathol. Bacteriol. 1959, 77, 371-380. [CrossRef]

62. Struble, E.B.; Ma, L.; Zhong, L.; Lesher, A.; Beren, J.; Zhang, P. Human Antibodies Can Cross Guinea Pig Placenta and Bind Its Neonatal Fc Receptor: Implications for Studying Immune Prophylaxis and Therapy during Pregnancy. Clin. Dev. Immunol. 2012, 2012, 538701. [CrossRef]

63. Ramos, L.; Obregon-Henao, A.; Henao-Tamayo, M.; Bowen, R.; Izzo, A.; Lunney, J.K.; Gonzalez-Juarrero, M. Minipigs as a neonatal animal model for tuberculosis vaccine efficacy testing. Vet. Immunol. Immunopathol. 2019, 215, 109884. [CrossRef] [PubMed]

64. Coe, C.L.; Kemnitz, J.W.; Schneider, M.L. Vulnerability of placental antibody transfer and fetal complement synthesis to disturbance of the pregnant monkey. J. Med Primatol. 1993, 22, 294-300. [CrossRef] [PubMed]

65. Fujimoto, K.; Terao, K.; Cho, F.; Honjo, S. The placental transfer of IgG in the cynomolgus monkey. Jpn. J. Med. Sci. Biol. 1983, 36, 171-176. [CrossRef] [PubMed]

66. Coe, C.L.; Lubach, G.R.; Izard, K.M. Progressive improvement in the transfer of maternal antibody across the order Primates. Am. J. Primatol. 1994, 32, 51-55. [CrossRef]

67. Scheffer-Mendoza, S.; Espinosa-Padilla, S.E.; López-Herrera, G.; Mujica-Guzmán, F.; López-Padilla, M.G.; Berrón-Ruiz, L. Reference values of leukocyte and lymphocytes populations in umbilical cord and capillary blood in healthy Mexican newborns. Allergol. Immunopathol. 2020, 48, 295-305. [CrossRef] 